\title{
The Media and Post-Election Peacebuilding in Nigeria, 1999-2015
}

\author{
Mathias Jarikre
}

\begin{abstract}
In democracies, the media plays a pivotal role in post-election peacebuilding. Beyond setting the political agenda, the media in Africa also addresses the challenges of electoral conflict and violence, security, and post-election peacebuilding. This article examines the role of the media in the electoral process in relation to postelection peacebuilding in Nigeria since 1999. Specifically, it highlights the Nigerian media experience with reflections on windows of opportunities for post-election peacebuilding. Content analysis is used to discuss the peacebuilding objectives of the Nigerian media election coverage, editorials, and media programs. The article concludes that the media undermines the impact of its role on conflict dynamics because of selfish interests. It is, therefore, recommended that the media re-embrace professionalism to prevent election violence and ensure peacebuilding.
\end{abstract}

Keywords media, election, peacebuilding, electoral violence, democratic practice

\section{Introduction}

The role of the media in democratic processes in Africa, especially in Nigeria, predates the first democratic election in 1956, as it stimulated a consciousness of self-rule and the imperative of dethroning colonial rule in Africa. The media was a potent instrument that galvanized nationalist movements. In fact, Nigeria owed the quick attainment of her independence to the dedication and dynamism of the Nigerian press during the years of nationalism (Azuh 2016). However, the difference between the historical account of the robust media campaign against colonialism and post-independence military dictatorships in Africa and the contemporary role of the media in emerging democracies such as Nigeria presents a paradox. This is because the media has been overtly or covertly implicated in electoral malfeasances. The implication is that electoral malpractices in Nigeria usually garner negative reactions from the public, reactions which become very destructive, especially when exacerbated by publication of inaccurate information 
or controversial results by the media.

Since the return to civil rule in May 1999, democratic practice in Nigeria has been subjected to several forms of abuse and misuse. Essentially, desperate political actors have attempted to undermine political and electoral processes to further selfish interests or hold onto power arbitrarily. Their actions have not only aroused the ire of the polity, but also posed a formidable threat to the country's nascent democracy. Jega (2011) observed that if elections are poorly managed, fraudulently conducted, and/or characterized by intense conflicts and violence, they become mere procedural "democratic" rituals of no consequence insofar as good governance and democratic consolidation are concerned. Therefore, the more fraudulent and conflict-ridden elections are, the higher the chances of such elections merely perpetuating arbitrary rule, undermining a transition to democracy, and creating instability in the polity (Akinwalere 2013).

The current democratic government of Nigeria, which has been in place since 1999, was earned with blood, sweat, and tears as it took many years of struggle to overthrow the military dictatorship. Therefore, when the political actors who represent the two elected branches of government (executive and legislature) are having issues with political processes (especially election issues), and the third branch (judiciary) appears to be constrained in upholding democracy, there is a fourth force in the mix, the media, that offers help at critical junctures. The media in real terms is more powerful and responsive to the needs of society than the traditional branches of government. This is because the media retains the capacity to act independently and to assume the role of gatekeeper when the traditional arms of government and their agents seem to have abdicated their roles.

At the same time, media programming and reporting have been known to stimulate election risk factors, such as spontaneous electoral violence, hate, and negative campaign messages, that individually or collectively impede the polity. It is in this sense that Wolfsfeld $(2004,8-10)$ points out the potential of a free, independent, and pluralistic media to be a sort of double-edged sword. On the one hand it can provide a robust platform for debate and divergent opinions, while, on the other hand, it may be misused for propaganda purposes, inciting hatred, and spreading rumors to artificially create tension. Within Africa, post-election violence in the 2007 Kenyan presidential elections, in which 1,133 people were killed and over 600,000 persons were internally displaced, is an often cited example of the negative role of the media (Elchahabi and Gallagher 2015). Therefore, the challenge confronting the media in (post-) election peacebuilding is how to achieve the delicate balance of information or "information equilibrium" (Koven 2004) in performing its essential role in the democratic process.

The media, comprising the traditional (television, newspaper, and radio) and new media (social media sites, blogs, emails, and other new social media 
platforms), has been recognized as the public watchdog of democracy (Müller 2014). The emergence of new media platforms in democratic spaces appears to be expanding beyond definite borders. Increasingly and interestingly, the new media has also constituted a potent medium for political actors to disseminate information, propagate their ideals, as well as mobilize political participation. However, this article will limit the use of the term "media" to the traditional mediums of television, newspaper, and radio. Whereas there is a large volume of related literature on the media and electoral violence, there is not so much on media and post-election peacebuilding. There is limited research on postelection peacebuilding in relation to measuring the impact of the media and the transition towards peace and democracy after a violent electoral process in Nigeria. Even more lacking is an overarching strategy to develop identifiable post-election peacebuilding indicators to measure the impact of media assistance in peacebuilding. This article is an attempt to fill these gaps by profiling media activities in post-election peacebuilding in Nigeria. To do this, the following questions frame this work: what is the nature of electoral conflict in Nigeria? What are the policy mechanisms in place for ensuring media agency in postelection peacebuilding in Nigeria? How has compliance with or contradiction of the policy mechanism impacted post-election peacebuilding?

\section{Media Related Electoral Violence in Nigeria (1999-2015)}

Since 1999, Nigeria's electoral body, the Independent National Electoral Commission (INEC), has conducted five general elections: 1999, 2003, 2007, 2011, and 2015. These elections have been characterized by ballot-fraud, intimidation, and violence. The Human Rights Watch reported that over one hundred people were killed and several others injured before, during, and after the general and local government elections in 2003 (Human Rights Watch 2004). As earlier mentioned, media complicity has contributed to some election infractions that resulted in violent conflicts. These infractions include the violence that erupted in Warri and its environs after a local radio station, "Radio Jeremi" (JFM), falsely declared the gubernatorial candidate of the Alliance for Democracy (AD), Chief Great Ovedje Ogboru, as the winner of the 2003 governor election of Delta State in South-south Nigeria, instead of Chief James Onanefe Ibori, the candidate of the Peoples' Democratic Party (PDP), who actually won the election. Also, in the build-up to the 2007 general elections, key personalities jockeying for elected positions at the state level such as Chief Marshall Harry (Rivers State), Engineer Funsho Williams (Lagos State), and Dr. Ayo Daramola (Ekiti State) were murdered (Reuben Abati 2006). Post-election violence that occurred following the April 2011 presidential election resulted in the deaths of over 800 people including ten members of the National Youth Service Corps and over 65,000 were 
internally displaced in the Northern states of Adamawa, Bauchi, Borno, Gombe, Jigawa, Kaduna, Kano, Katsina, Niger, Sokoto, Yobe, and Zamfara (Human Right Watch 2011; Maduekwe 2015). The intensity of the 2011 post-election violence threatened national cohesion as it lent credence to the prediction of the U.S. Central Intelligence Agency (CIA) which stated that by 2015 Nigeria would cease to exist. The prediction was credited to a National Intelligence Council discussion paper entitled "Mapping Sub-Saharan Africa's Future," but it has been refuted and does not represent official U.S. policy (Campbell 2012). The sources of these electoral tensions were largely endogenous, although they were also associated with the complimentary role of the media. In fact, the Presidential Committee on 2011 Post Election Violence set up by President Goodluck Jonathan called out the media for failing to be discreet in their reporting of inciting comments credited to General Mohammadu Buhari (presidential candidate of the Congress for Progressive Change (CPC) in the 2011 election).

The sources and specters of electoral conflict, violence, and malpractice orchestrated in these elections remained essentially the same with only the dramatis personae having changed. The history and trajectories of electoral violence in Nigeria, shifting as they are across time and space, are replete with media complicity in terms of affiliation, content, and reportage. Also, this was in contrast with the unity of purpose that was the hallmark of the media in the struggle against colonial rule and the struggle for independence. Indeed, the role of the media in the electoral processes since the Fourth Republic (1999 2015) does not only reflect a paradox but is also insidious. For instance, prior to the 2003 general elections, the Economic and Financial Crime Commission (EFCC) accused some political aspirants of fraud and related offenses. But rather than being tried in a court, they were prosecuted and convicted by the media, becoming villains in the eyes of the public. However, like a comedy of errors, these media convicts were likewise projected as presumptive candidates for elective positions and public office by another section of the media. For instance, Alexander Odaibo, the Deputy Vice Chancellor at Igbinedion University in Nigeria, was apt when he observed that "the same press that condemned Buhari (prior to the last election) turned round to praise Buhari, oh he never said he would Islamize Nigeria; he was quoted out of context, ... so we saw that the press worked to make him president" (Ero 2015, 26).

Since 1999, hate speech and acrimonious campaigns have been a common denominator in the electoral process. But, in 2015, the unwholesome use of media platforms and reportage appeared to have escalated the haemorrhaging electoral process with a devastating impact on the Nigerian political space. Some political actors have consistently used the media to convey discriminatory epithets to insult and stigmatize others on the basis of their race, ethnicity, gender, sexual orientation, or other forms of group membership as well as using gestures, conduct, or writings which could incite people to violence or prejudicial action. 
For instance, an anti-General Mohammadu Buhari (presidential candidate of the All Progressive Congress (APC) in the 2015 election) advertisement entitled "Enough of State Burials" was placed in the front pages of two national newspapers and a documentary aired on some television channels. Similarly, "The Lion of Bourdillon," a controversial TV documentary aired by both Africa Independent Television (AIT) and Nigeria Television Authority (NTA), was designed to attack an opposition party chieftain, Senator Ahmed Tinubu, the national leader of the then opposition party APC (now the ruling party in Nigeria), in a purely slanderous hate campaign. Consequently, the APC chieftain sued AIT claiming \$NGN 150 billion in damages, but the parties settled out of court after AIT tendered a public apology to the litigant. However, it should be observed that the station took the democratic election media campaign beyond the journalistic boundary.

In another breath, the degree to which the media was involved in the conspiracy against the state and the ruling party in the 2015 elections is arguable. What is clear, however, is that the handling of some critical flaws in the elections by the Nigerian media reflected that the media poses a serious threat to postelection peacebuilding. In short, according to Sam Oyovbaire, former Minister of Information of Nigeria, "even the under-age voting that was caught all over the whole place, the media did not do anything about it; it was not even on the agenda ... the Nigerian media set up the agenda, it can also kill any agenda" (Tell Magazine 2015). In addition, the media also ignored the negative perception that is occasioned by conflicting judgments of election petitions delivered at election tribunals and various divisions of the Court of Appeals. Such judicial contradictions not only resulted in untold hardship to litigants in their quest for justice, but further cast aspersions on the judges and the media.

Whilst the indictment of the media by the presidential panel on the 2011 post-election violence and Oyovbaire's observation were enough to expose how its affiliation, content, and reportage severely undermined the viability of the electoral process in Nigeria, it is also important to recognize the socioeconomic space that would implicitly inhibit practice or is externally imposed on its critical role. For instance, the way elections are reported in the Nigerian news media smacks of corruption. The corruption syndrome is known as "brown envelope journalism" - cash bribes for reporters typically come in brown envelopes. Ostensibly, the money is given to cover journalists' travel costs and other expenses, but the understanding is clear: the money affects the way stories are reported. And this is what allegedly happens during elections. It is easy to condemn journalists for taking bribes, but, like most stories of corruption, the reality is that there are some complexities involved. Nigerian journalists are among the worst paid reporters in Africa, and bribes are an important source of income. Furthermore, adherence to the fundamental principles of balance and objectivity is almost always sacrificed on the altar of the proprietor's political 
interests. That is, the character of political reporting and commentary is entirely dependent on the media ownership structure and the owner's relationship with the political system (Aghamelu 2013). It was observed that some media outlets exaggerated matters and distorted the facts. This was prevalent amongst media houses owned by politicians where media content and reportage were obviously tilted in favor of the political party of their directors.

\section{Contextual Discourse}

Broadly speaking, the political arena by its nature is characterized by competition and conflict between individuals, groups, and interest groups, each struggling to ensure that its interest prevails (Godowoli 2002). In Nigeria, the political arena is contentious with unimaginable clashes among differing socio-political and economic interests. This further explains why it does not take long to ignite the flames of polarization along ethnic, religious, and political lines leading to acrimony, unresolved conflicts, intimidation, and harassment of the opposition. The spate of electoral fraud and violence, and the imperatives of establishing democratic norms in order to stabilize the polity in Nigeria, pose a critical challenge to post-election peacebuilding, and the media should assist in addressing this challenge. It is pertinent, therefore, to state here that electoral fraud, violence, conflicting judgments on election petitions, and the other challenges to post-election peacebuilding that are confronting Nigeria threaten the country's emerging democracy. Inevitably, this has no doubt placed upon the media, as the fourth estate of the realm, the critical responsibility of halting or restraining the downward slide of the polity as a result of violence prone elections.

Politics as a universal phenomenon involves the congregation of people, and, as such, disagreement is bound to occur at any level (ibid.). In zero-sum politics, as it is practiced in Nigeria, political activities accentuate socio-political tension, create ethnic and religious division, and, in some instances, manifest violent conflicts. This is evident by the activities of the different political parties and actors in the Nigerian democratic space, especially since the transitional buildup by the General Abdulsalami Abubakar junta in 1998. In fact, the struggles and competition have more often than not led to electoral violence before, during, and even after an election. One of the multiple challenges confronting democratic practice and processes in Nigeria, and indeed Africa, is electoral violence and escalated conflict. Electoral violence as a physical manifestation of socio-political conflict has assumed a critical dimension in Nigeria's democratic space and history.

According to Friedrich Ebert Stiftung (2001, 1), electoral violence is any action "geared towards winning political competition or power through violence, subverting the ends of the electoral and democratic process." It is in this sense 
that Jeff Fischer $(2002,8)$ defines electoral violence as "any random or organized act that seeks to determine, delay, or otherwise influence an electoral process through threat, verbal intimidation, hate speech, misinformation, physical assault, forced 'protection, blackmail, destruction of property, or assassination." Electoral violence can be classified into physical and non-physical forms of violence. The former includes kidnapping, killing, and destruction of property while the later involves threats, intimidation and blackmail (Joint Task Force on Electoral Assistance 2011, 15).

Electoral violence can occur at any given period in the electoral process. To understand the dynamics and trajectories of violent conflict in the election process and the need to develop conflict prevention and management strategies, Lisa Kammerud $(2012,2)$ recommends the use of electoral violence conflict mapping. It is a systematic method of mapping violent conflicts through the electoral circle approach, usually segmented into three stages: the pre-election, election, and the post-election phases. This is done because each phase in the circle manifests different kinds of violent conflict. This electoral violence mapping not only is aimed at identifying the dynamics, but also provides assistance to countries struggling with electoral violence.

Orji and Uzodi (2012) identified a number of issues responsible for electoral violence in Nigeria, and categorized them as either remote or immediate causes. According to the authors, the remote causes include: cleavage structure, saliency of ethnicity in Nigerian politics and communal tensions, decline in trust and social capital among communities, culture of impunity, economic vulnerabilities, erosion of trust in the electoral and justice system, and low levels of internal party democracy. The issues that could immediately trigger electoral violence include "issues relating to the integrity of elections, use of inflammatory rhetoric, and changes in political institutions" (ibid., 14). Although, the authors did not include the media in any of the categories, without a doubt the negative impact of the media has overtly or covertly stimulated, amplified, and accentuated some of these factors. The identification of the issues that cause electoral violence is not gratuitous; rather, as election experts argue, it enables stakeholders to develop a "strategic design of prevention and management programs that can forestall recurrence" (Matlosa, Shale, and Motsamai 2010, 7).

Electoral violence as a component of political conflict is an inherent and inevitable social phenomenon. It is not simply destructive, but is a strong motivating force for democratic development and peacebuilding. Therefore, it is how conflicting parties attempt to deal with it that forms the bedrock of conflict management and transformational peacebuilding. Essentially, it requires conscious multi-track efforts to de-emphasize political violence in order to strengthen democratic practice and institutions of governance as well as engender a peaceful society. Post-election peacebuilding provides opportunities to all stakeholders and sectors of society to be involved in activities promoting security, 
reducing tension, and building peace. Fidelis Chuka Aghamelu (2013) notes that though the issue at stake is the responsibility of all stakeholders in the body polity, there is, however, a rationale in assigning this responsibility to the mass media given its position as the fourth estate of the realm. What this presupposes is that media complicity can generate, feed, and accentuate systemic social conflict in the democratic space, which includes post-election violence.

The salient role of the media as a potent social instrument is predicated on its capacity to set the agenda for the people (McCombs and Shaw 1972). Many scholars explicate the effect of media on society with some stating that it has a very powerful influence, although others view such influence as minimal. The mandate of the media in democratic societies is to educate, inform, and entertain the people (Dukor 1998). Nevertheless, the media has often responded to the dynamics of society and has therefore witnessed a corresponding evolution in its professional engagements. In addition to the aforementioned roles, Ikechukwu Enoch Nwosu (2004) identifies other functions of the media including socialization, opinion generation, mobilization, crusading, and ombudsman.

Beyond framing (the controlling or shaping of news in a pattern that will not incite others into expanded or multiple conflicts) and providing platforms through which various options are considered for the resolution of conflict (McCombs and Shaw 1972), the media during election processes contributes to national development and nation-building. It is in this sense that Tony Iredia $(2007,11)$ submits that the most potent strategies and the technical format for effective public enlightenment belong to the media because the electoral commission (election conducting body) does not have the capability in terms of a media platform to undertake voter education. Reflecting on the Nigerian situation, he goes further to underscore the limited capacity of the information department of the election conducting body in the area of voter education in relation to the image-making ventures which many information departments of electoral commissions undertake.

Since the 1990s, there has been increasing interest in the role of the media in peacebuilding (Spurk 2002). Scholars and practitioners have used the concept of peacebuilding within the context of their engagements and vintage position based on their objectives as the literature is multifaceted and multidimensional. However, there is an overwhelming reference to Boutros Boutros-Ghali's (1992, 21) definition of peacebuilding "as a range of actions to identify and support structure which will tend to strengthen and solidify peace in order to avoid a relapse into conflict." Within the broader or narrower sense of peacebuilding activities lies the inherent role (indirect or direct conflict related programing) of media assistance in a post-conflict society. Thus, the role of the media in postelection peacebuilding is predicated on the positive impact of the media to prevent relapse into violent conflict by ensuring that violations of electoral law are addressed so that impunity of election violence is not entrenched. 
Jarikre (2016), drawing from the works of several scholars (Galtung 1976; Fisher 1993; Tschirgi 2004, 2008; Sarigiannidis 2007), opines that the existing literature on peacebuilding is both diverse and open-ended, some assuming broad spectrum while others have limited outcomes that are based on narrow or normative aspects of peacebuilding. He further stresses that the literature on peacebuilding depicts an academic license whereby its meaning is derived from the scholar's or practitioner's position based on the objective(s) of the activity. However, irrespective of the conceptual framework of peacebuilding, it cannot be isolated from the peacebuilding vision of Boutros-Ghali (1992). The narrow aspects of peacebuilding activities place a premium on the contributions of social entities and institutions including faith-based groups, civil society groups, academia, the judiciary, the media, etc., aimed at sustaining peace. It is in this sense that Lisa Schirch $(2008,8)$, explains that peacebuilding, as an integrative concept, teaches that conflict is normal and germane to social changes, if handled constructively.

There is greater attention given to peace journalism and a stricter examination of media assistance in peacebuilding activities. However, the debate on the fusion of the media and peacebuilding as a field is still in its nascent stage with the roles of journalists unclear and no established method of measuring impact (Spurk 2002). Peacebuilding is basically a concept used in conflict zones or periods of crisis. Hence, it is usually preceded by a nominal such as post-war, post-conflict, post-crisis, or post-election peacebuilding, which is the thrust of this paper. Postelection peacebuilding, therefore, involves active measures to ensure that a society does not relapse into violent conflicts after democratic elections.

Drawing from the underpinning nature of peacebuilding as a process to strengthen structures that would either create or support the creation of necessary conditions for sustained peace (Barbero et al. 2004), peacebuilding is not based on persuasion or manipulation; rather it is based on the value of empowerment in post-conflict societies (Jarikre 2014). It is in this sense that we hear of peacebuilding efforts in relation to development, security sector reforms, resettlement of internally displaced persons, reintegration and reinsertion of former combatants, building institutions for and the capacity of a displaced population in post conflict society through microcredit schemes, and other empowerment activities. Invariably, peacebuilding activities are designed as a means of securing societal peace and the media has often been used to facilitate such processes.

The debate and literature on the role of the media in peacebuilding often depict the media as a support instrument of peacebuilding agencies and practitioners even though the media in peacebuilding can be a stand-alone. The concern here, therefore, is to identify realistic frameworks and programing within the Nigerian media space to support it as a stand-alone in post-election peacebuilding. The structure of electoral violence in Nigeria and the challenges of 
the media in a complex and shifting political process are beyond the recognized traditional peacebuilding theoretical frameworks. Therefore, it is imperative to devise a strategic operational model for the media to meet the challenges of postelection peacebuilding in relation to conflict sensitive reportage/programing and to keep the media from negatively impacting the electoral process. An independent model of intervention to prevent electoral violence and to nimbly navigate a transition to peace and democracy is by giving balanced opinions, ensuring information equilibrium, discouraging and countering hate speech, influencing society before violence, and addressing the issues even afterwards. One instrument that tends to direct media activities within the sphere of postelection peacebuilding in Nigeria is the Nigerian Media Code of Election Coverage by the Independent National Election Commission (INEC).

Though the INEC uses media programming to fulfill its mandate of facilitating political party and voter education, running campaigns on non-violent elections, disseminating information on the electoral processes, and addressing conflict prevention and post-election peacebuilding, other organizations and political parties also use the independent media to further their economic and political interests. Considering the constructive and destructive potentials of the media in electoral process, the INEC designed the Nigerian Media Code of Election Coverage to ensure that the media carries out its critical role in elections without causing harm. Though the Media Code is an instrument designed to guide media activities in the electoral process, it appears to highlight the media's role as an independent post-election peacebuilding agent. Therefore, this identifies the media as a stand-alone agent in post-election peacebuilding.

\section{The Nigerian Media Code of Election Coverage}

The inordinate use of the media as a mass mobilization medium to incite the vulnerable to electoral violence within the Nigeria's democratic experience poses a threat not only to the democratic fabric of Nigerian society but also to the spread of democracy within the West African sub-region. Therefore, it has brought to the fore the issue of ethical standards. The Nigerian Media Code of Election Coverage is the INEC's election governance framework to regulate media activities as it affects election management. The code is a fusion of relevant institutional frameworks and instruments including the Electoral Act 2010 (as amended), the Nigeria Broadcast Code (as revised), and the Nigeria Press Organisation Code of Ethics for Nigerian Journalists.

The Media Code is situated within the sphere of the liberal approach to peacebuilding, as Goran Hyden $(2015,1013)$ argues, "liberal peacebuilding demands structures that can moderate conflict ... and as a peacebuilding package that is monolithic and in which they are treated as 'texts' to be learnt 
and adopted." The Code does not only prescribe the ethos and best practices for the media, but also serves as a catalyst for stabilization of the polity, conflict prevention, and post-election peacebuilding. There is a significant positive relationship between the content of the Code and best media practices as well as post-election peacebuilding, if they adopt and adhere to the Code. Considering the negative impact of the media, the prescription of the Code to the media in post-election peacebuilding cannot be underestimated; hence, the need to outline some fundamental aspects that have fostered post-election peacebuilding and conflict prevention.

The media has overtly or covertly contributed to the entrenched culture of electoral violence since 1999, which has threatened Nigeria's fledgling democracy and the fabric of society. As a strategic response to the realities of electoral violence associated with the role of the media, a framework to reduce drivers of electoral violence and to ensure that the media could work around and in electoral conflict was adopted by media stakeholders in October 2014. Although, there are several media governance frameworks such as the Nigeria Broadcast Code (as revised) and the Nigeria Press Organisation Code of Ethics for Nigerian Journalists mentioned above, the adoption of a Media Code for election coverage was imperative for two reasons. First, the 2011 post-election violence was a result of indiscreet media reports that contained inciting comments credited to an opposition presidential candidate. Second, the Code is a strategic institutional response to stave off the impeding disintegration of Nigeria, which was predicted by some in the United States.

The content of the Code explicitly prescribes the social obligation of the media in the electoral process in terms of equitable access for all political parties to broadcast mediums, professional and social responsibilities, ethical conduct, endorsements of political platforms, political advertisements, and editorials. In addition, the Code stipulates deliberately that editorials and opinion pieces must refrain from hate speech, intemperate language, airing pejorative comments, hateful or inciting word and messages, and abusive editorial claims of any guise as well as a subscription to a no-hate-speech memorandum of understanding.

Pointedly, the creation of the Code is a reflection of the influence of the media on policymakers, and election implementation agencies, such as the INEC, recognized the value of designing a framework to respond to the constructive and deconstructive potential of the media. For instance, the Code recognizes that "the media enables voters to make informed choices by providing information that enhances their knowledge of electoral processes ... therefore it is desirable to have a set of guidelines that regulate the professional conduct of the media and journalists during elections" (Independent National Electoral Commission 2014, 1). The Code outlines virtually everything the media needs to do to achieve conflict sensitivity and conflict prevention in the electoral process and become a critical component of post-election peacebuilding. In fact, the Code is the 
main tool of the Commission to galvanize violence-free electoral processes by inciting the media to reduce electoral aggression, to prevent violent conflicts, and proactively report early warning signals of possible outbreaks of violence before, during, and after elections. The Code, in a sense, restricts the media from being part of the conflict by avoiding construction or reconstruction of conflict identities, instead using their programs to build an inclusive political community.

Furthermore, the media as a profession encapsulates ethical nuances that guide its engagement. The Code, therefore, calls for a thoroughly professional media practitioner who should exude integrity, respect, confidentiality, and credibility with a strong commitment to state the facts of political or electoral issues in order to defuse adverse public opinion. It will suffice that the objective of the Nigeria Media Code of Election Coverage is premised on ethical standards and best practices that align with the core post-election peacebuilding goals to support the creation of necessary conditions for sustained peace.

\section{Media Programs and Editorials}

Although there are no specific media programs for post-election peacebuilding within the Nigerian media space, there are several media programs, even in their omnibus nature, designed to address issues of post-election peacebuilding and conflict prevention. The media, in its traditional roles as watchdog, gatekeeper, and agenda setter, provides platforms for dialogue to assist conflicting parties improve their relationships and to build bridges over political divides. Beyond political news and voter education, there are sundry political oriented programs designed to provide platforms for dialogue and to stimulate public debate among disputing parties in the electoral process as well as participatory citizenship for interactive post-election peacebuilding. Some of the programs include Sunrise Daily and Politics Today aired by Channels Television and Focus Nigeria and Kakaaki - the African Voice on Africa Independent Television (AIT). These programs are reputable for their focus on social dialogue. The programs adopt the strategic level approach which targets leaders of society and political actors in order to bring on air disputing parties, critical stakeholders, and experts on election matters to stimulate political discourse and conversations.

The importance of these programs includes the cross-cutting media functional mix with its problem solving orientation to promote peace-build bridges between and amongst groups, improve communication and relationships, as well as depolarize peoples' attitudes and behavior toward each other. For instance, Channels Television's Sunrise Daily, a discussion program, regularly invites two or more persons from conflicting parties on election issues to an open dialogue on a live show. Notable participants include some members of the two opposing parties in the violent governorship elections in Bayelsa and Kogi States 
in 2016, and the candidates in the national assembly re-run elections in Rivers State, also in 2016, were invited in light of the aggression and violent behavior of their party members. These interactive programs include participatory audience engagement mechanisms through phone-in and social media comments (Twitter, emails, and SMS). In this way, the three anchors of the program, Chamberlain Usoh, Suleiman Alledeh, and Maupe Ogun, tried to find common ground between these parties, build bridges among political actors/parties, provide confidence to negotiate, and engender positive relationships to lessen polarization between conflicting political interests and parties. It is worth noting here that these interactive programs and audience engagement mechanisms are elite based. Although these media participatory platforms have been effective with increased elite participation, there is a large number of marginalized people in rural areas, including females and the poorest of the poor, who have zero access to media engagement due to lack of electricity or inability to afford televisions. In any case, there is every reason to believe that the discussions are likely to have significant effect on the polity, especially attempts at reconciliation and peacebuilding (Wolfsfeld, Alimi, and Kailani 2008) and the building of relationships between the populations involved (Lederach 1998).

Similarly, in the post-election phase, the media has consistently served as a catalyst and platform for the sharing of opinions where perceived corrupt judges and conflicting election judgments are prosecuted. Pointedly, the media has been invaluable in the peacebuilding process by facilitating citizen participation in interrogating the legal procedures and outcomes of election cases at tribunals and courts.

Since 1999, hate speech has become prevalent in election campaigns. The media has also aggravated the situation, considering how the citizenry buys into some outlets' divisive opinions, the aforementioned "The Lion of Bourdillon" television program being one example. However, there are media outfits poised to de-escalate the steady haemorhaging campaign hate speeches. A case in point is an editorial in the This Day Live (2015) titled "Hate Speech, Violence and 2015 Election." The authors joined the National Human Rights Commission and the Advertising Practitioners Council of Nigeria to condemn the penchant of Nigeria politicians in promoting "divisive rhetoric that could push our fractious society into a serious crisis if care is not taken" (This Day 2015). Furthermore, the editorial enlightened the masses properly on hate and offensive rhetoric, while calling on media organizations to comply with relevant laws against hate speech that could incite people to violence before, during, and after the 2015 general election. 


\section{Conclusion}

From the foregoing, it could be observed that, since 1999, the media has played quite a significant role in the democratic process in Nigeria. However, there are instances where some media organizations and journalists have deliberately attempted to undermine the electoral processes, thereby arousing the polity and negatively impacting public safety. These dysfunctional electoral activities are inconsistent with the primary role of the media and have almost always worsened violent electoral conflicts. This article has identified several reasons for the unethical media practice which include, but are not limited to, pecuniary and selfish political interests of journalists and media company owners. The Nigerian Media Code of Election Coverage provides a framework for the media to ensure best practices of the journalism profession to forestall election violence and ensure peacebuilding. The preventive measure matrix of the Media Code is a means to an end, but it does appear to be an end in itself. Although in any democracy, a preventive, effective, and democratic media is indispensable to the electoral process, enabling the people to make their choices, one can observe a shift in Nigeria. The Nigerian media is now less concerned with balanced information than being a purveyor of hate speech and electoral conspiracies.

\section{References}

Abati, Reuben. 2006. “A Tough Moment for the Media." The Nigeria Village Square, October 6. http://nigeriavillagesquare.com/forum/threads/a-tough-moment-for-themedia.5527/ (accessed November 7, 2017).

Aghamelu, Fidelis Chuka. 2013. "The Role of the Mass Media in the Nigerian Electoral Process." Unizik Journal of Arts and Humanities 14 (2): 2-19.

Akinwalere, Ifedayo. 2013. "Brief History of Elections in Nigeria." News Now Online Magazine, September 3. https://newsnowmagazines.blogspot.com/2013/09/briefhistory-of-elections-in-nigeria.html (accessed June 10, 2017).

Azuh, Kingsley. 2016. “The Nigerian Press.” The Pointer, April 12. http://thepointernewsonline. com/?p=44698 (accessed October 9, 2017).

Boutros-Ghali, Boutros. 1992. "An Agenda for Peace: Preventive Diplomacy, Peacemaking and Peace-keeping." United Nations Document A/47/277, June 17, 1992. http://www. un-documents.net/a47-277.htm (accessed October 9, 2017).

Campbell, John. 2012. "U.S. Government Never Predicted Nigeria Break Up in 2015.” Council on Foreign Relations, May 16. http://www.cfr.org.blog-post,us-gov (accessed November 7, 2017).

Dukor, Maduabuchi. 1998. “The State and the Media in Africa." In Philosophy and Politics Discourse on Values and Power in Africa, ed. Maduabuchi Dukor. Lagos: Malthouse Press.

Elchahabi, Samer, and Adam Gallagher. 2015. “The Evolving Role of Media in Elections.” International Foundation for Electoral Systems, May 21. http://www.ifes.org/news/ 
evolving-role-media-elections (accessed March 24, 2016).

Ero, Adekunbi. 2015. “The Morning After." TELL, August 3.

Fischer, Jeff. 2002. "Electoral Conflict and Violence: A Strategy for Study and Prevention." International Foundation for Electoral Systems, White Paper 2002-01, February 5. http://www.ifes.org/sites/default/files/econflictpaper.pdf (accessed November 16, 2015).

Godowoli, Abdullahi. 2002. "Nature and Types of Conflict in a Democracy." In Introduction to Conflict Reporting in Nigeria, ed. Umaru Pate, 1 - 12. Lagos: Frankad Publishers.

Human Rights Watch. 2004. "Nigeria's 2003 Elections: The Unacknowledged Violence." June. https://www.hrw.org/reports/2004/nigeria0604/nigeria0604.pdf (accessed October 9, 2017).

Human Rights Watch. 2011. "Nigeria: Post-election Violence Killed 800.” May 16. https:// www.hrw.org/news/2011/05/16/nigeria-post-election-violence-killed-800 (accessed June 3, 2015).

Hyden, Goran. 2015. "Rethinking Justice and Institutions in African Peacebuilding" Third World Quarterly 36 (5): 1007-1022.

Independent National Electoral Commission. 2014. "The Nigerian Media Code of Election Coverage." http://www.inecnigeria.org/wp-content/uploads/2014/12 (accessed March 23, 2016).

Iredia, Tony O. 2007. "Information Dissemination, Voters' Mobilization and Election Monitoring in Nigerian Electoral Process." In Improving the Fortunes and Destiny of Nigeria Through the Ballot Box, ed. Ogun M. Abuja: Catholic Laity Council of Nigeria. Iruonagbe, Tunde Charles, David Imhonopi, and Federick Olusola Ahmadu. 2013. "A Conceptual Review of Mass Media and Political Violence in Nigeria between 1999 and 2013." New Media and Mass Communication 20: 12-20.

Jarikre, Mathias. 2014. "Mobilizing Local Capacity for Security and Peacebuilding: Community Development Committees in Post Conflict Warri Area, Delta State, Nigeria." Ibadan Journal of Peace and Development 3-4: 162-178.

Jarikre, Mathias. 2016. "Peacebuilding: The Relational Dimension of the Three-PointsAgenda of Delta State Government, Nigeria (2007-2015)." South South Journal of Culture and Development 18 (1): 27-69.

Jega, Attahiru. 2011. "2011 General Elections and the Consolidation of the Democratic Process in Nigeria." Text of a Public Lecture Delivered at the Centre for Research and Advocacy, University of Lagos, Nigeria.

Joint Task Force on Electoral Assistance. 2011. "Thematic Workshop Summary Report: Elections, Violence and Conflict Prevention." Conference Organized by United Nations Development Programme, European Commission, and International IDEA, Barcelona, June 20-24. http://www.undp.org/content/dam/brussels/docs/Other/ JTF\%202011.06_Summary_report-Barcelona_workshop_Elections\&conflict.pdf (accessed November 7, 2017).

Kammerud, Lisa. 2012. "An Integrated Approach to Elections and Conflict.” International Foundation for Electoral Systems, White Paper, April. http://www.ifes.org/sites/ default/files/integrated_approach_to_elections_and_conflict.pdf (accessed November 12, 2015).

Koven, Ronald. 2004. "An Antidote to Hate Speech: Journalism, Pure and Simple." In Media: Conflict Prevention and Reconstruction, ed. Barry James. Paris: United Nations 
Educational, Scientific and Cultural Organization.

Lederach, John Paul. 1998. Building Peace: Sustainable Reconciliation in Divided Societies. Washington D.C.: United States Institute of Peace Press

Maduekwe, Ojo M. 2015. "Post-election Violence and the Media: The media has a critical role to play in curbing post-election violence in Nigeria." This Day Live, March 3. http. www.nigeriaelections.org/blogpost/146/2015-poll-post-election-violence-and-themedia (accessed April 20, 2016).

Matlosa, Khabele, Victor Shale, and Dimpho Motsamai. 2010. "Preventing and Managing Violent Election-Related Conflicts in Africa: Exploring Good Practices." Conference Proceedings Report of EISA 4th Annual Symposium, Rosebank, South Africa, November 17-18, 2009. https://www.eisa.org.za/pdf/symp09cp.pdf (accessed November 20, 2015).

McCombs, Maxwell E., and Donald L. Shaw. 1972. "The Agenda-Setting Function of Mass Media." Public Opinion Quarterly 36 (2): 176-187.

Müller, Lisa. 2014. Comparing Mass Media in Established Democracies. United Kingdom: Palgrave Macmillan.

Nwosu, Ikechukwu Enoch. 2004. Mass Media and Nigerian Society for Mass Communication Students and Professionals. Enugu: Afrika-Link Books.

Orji, Nkwachukwu, and Nkiru Uzodi. 2012. Post Election Violence in Nigeria: Experiences with the 2011 Elections. Abuja: Policy and Legal Advocacy Centre.

Barbero, Christian, Sarah Bayne, Emery Brusset, Susanna Campbel, Jos de la Haye, and Manuela Leonhardt. 2004. "Conflict Sensitive Approaches to Development, Humanitarian Assistance and Peacebuilding." http://www.international-alert.org/ sites/default/files/Training_DevelopmentHumanitarianAssistancePeacebuilding_ EN_2004_0.pdf (accessed November 7, 2017).

Schirch, Lisa. 2009. "Strategic Peacebuilding: State of the Field." Peace Prints: South Asian Journal of Peacebuilding 2 (1): 1-16.

Spurk, Christoph. 2002. "Media and Peacebuilding Concepts, Actors and Challenges." Swiss Peace, Working Paper 1/2002, November. http://www.swisspeace.ch/fileadmin/ user_upload/Media/Publications/WP1_2002.pdf (accessed April 14, 2016).

Stiftung, Friedrich Ebert. 2001. "Political and Electoral Violence in East Africa." Center for Conflict Research, Working Paper No. 2. http://library.fes.de/pdf-files/bueros/ kenia/01398.pdf (accessed February 13, 2016).

This Day Live. 2015. "Hate Speech, Violence and 2015 Election." January 25. http://www. thisdaylive.com/articles/hate-speech-violence-and-2015-election/200026/ (accessed June 3, 2015).

Wolfsfeld, Gadi. 2004. Media and the Path to Peace. Cambridge: Cambridge University Press.

Wolfsfeld, Gadi, Eitan Y. Alimi, and Wasfi Kailani. 2008. "News Media and Peace Building in Asymmetrical Conflicts: The Flow of News between Jordan and Israel." Political Studies 56: 374-398.

Mathias Jarikre is a lecturer in the Peace Studies and Conflict Resolution Programme of the Department of Political Science, Faculty of Social Sciences, National Open University of Nigeria. 
He holds a Ph.D. in Peace and Conflict Studies, is a member of various professional bodies, and is currently the second vice president of Society for Peace Studies and Practice (SPSP), Nigeria. His research interest is in the area of peacebuilding and some of his articles include "Mobilizing local capacity for security and peacebuilding: community development committees in post-conflict Warri, Delta State, Nigeria," "Peacebuilding: the relational dimension of the three-point-agenda of Delta State Government (2007-2015)," and "Development intervention and the imperative of peace and conflict impact assessment in the Niger Delta."

Submitted: June 20, 2016; Revised: July 20, 2017; Accepted: July 24, 2017 
